\title{
Vers une conception centrée sur l'utilité
}

Une analyse de la co-construction participative et continue des besoins dans le contexte des technologies émergentes

Towards a usefulness-centered design: an analysis of participative and continuous co-construction of requirements in the context of emerging technologies

\section{Émilie Loup-Escande}

\section{(2) OpenEdition}

1 Journals

\section{Édition électronique}

URL : http://journals.openedition.org/activites/2637

DOI : 10.4000/activites.2637

ISSN : 1765-2723

\section{Éditeur}

ARPACT - Association Recherches et Pratiques sur les ACTivités

Référence électronique

Émilie Loup-Escande, "Vers une conception centrée sur l'utilité », Activités [En ligne], 8-2 | octobre 2011, mis en ligne le 15 octobre 2011, consulté le 14 septembre 2020. URL : http:// journals.openedition.org/activites/2637

Activités est mis à disposition selon les termes de la licence Creative Commons Attribution - Pas d'Utilisation Commerciale - Pas de Modification 4.0 International. 


\title{
Vers une conception centrée sur l'utilité : Une analyse de la co-construction participative et continue des besoins dans le contexte des technologies émergentes
}

\author{
Émilie Loup-Escande \\ Équipe Presence \& innovation - Laboratoire des Arts et Métiers ParisTech d'Angers \\ 4 rue de l'Ermitage - 53000 Laval \\ emilie.loup-escande@ensam.eu
}

Thèse soutenue le 8 décembre 2010, à l'Université d'Angers, devant le jury composé de :

- Patrick Bourdot, Chargé de Recherche, CNRS, Examinateur

- Stéphanie Buisine, Ingénieure de Recherche, Arts et Métiers ParisTech, Examinatrice

- Françoise Détienne, Directrice de Recherche, CNRS, Rapporteure

- Jean-Claude Sagot, Professeur des Universités, UTBM, Rapporteur

- Simon Richir, Professeur des Universités, Arts et Métiers ParisTech, Directeur de thèse

- Jean-Marie Burkhardt, Maître de Conférences, Univ. Paris Descartes, Co-directeur de thèse

- Hervé Christofol, Maître de Conférences, Univ. d'Angers, Co-directeur de thèse.

\section{RÉSUMÉ}

L'objectif de cette thèse est d'assister et d'améliorer la prise en compte de l'utilité dans le processus de conception des artefacts issus des technologies émergentes. Cette question de l'utilité présente un intérêt certain dans la mesure où il existe une forte demande d'outillage pour traiter cette dimension de l'utilité dans la conception : la prolifération des Living Labs qui repose sur la conception participative en témoigne. Il n'y a pourtant pas, aujourd'hui, de cadre théorique ou méthodologique traitant explicitement de l'utilité pour guider la conception et pour définir les objectifs à atteindre. La définition comme la mesure de l'utilité sont peu définies dans la littérature, et il y a peu d'études s'intéressant spécifiquement aux contributions des méthodes de l'ergonomie à cette dimension d'utilité. Il en résulte également peu de préconisations à fournir aux concepteurs en termes d'utilité. Pour aboutir à des préconisations susceptibles d'enrichir les prescriptions caractérisant les modèles du processus de conception (en particulier, ceux de l'ingénierie), l'approche choisie a été d'observer le fonctionnement réel de la conception.

Cette thèse a été réalisée dans le contexte d'une Recherche-Action menée dans le cadre d'un projet réel de conception appelé 3DChild et ayant abouti à la réalisation du logiciel Appli-Viz'3D. Il s'agit d'un logiciel de Réalité Virtuelle au sens de génération par ordinateurs d'entités 3D interagissant en temps réel et se modifiant en fonction du comportement de l'utilisateur. Ce dispositif informatique vise à aider les professionnels de la petite enfance (marketeurs, ingénieurs et designers) à concevoir et à vendre des produits adaptés à l'enfant. Le logiciel Appli-Viz'3D consiste en la mise en place de prototypes de produits et de mannequins 3D dans deux environnements virtuels réalistes : une chambre d'enfant et une voiture.

Deux axes ont guidé ce travail de recherche.

Le premier a été de comprendre le sens que les notions d'utilité et de besoins prennent pour les concepteurs et la façon dont elles sont « outillées » pour les intégrer dans le processus de conception. Pour ce faire, nous nous sommes intéressés aux modèles, méthodes et outils utilisés ou préconisés dans la littérature du marketing, du génie industriel, de l'ingénierie des exigences, du génie logiciel, 
du design et de l'ergonomie des activités de conception. Nous avons également exploré, au moyen d'entretiens semi-directifs, les représentations qu'ont trois catégories de concepteurs quant à la notion d'utilité et aux éléments clés du processus de construction de besoins.

Le second axe a été d'étudier la contribution réelle des acteurs - concepteurs et utilisateurs - à la conception d'artefacts innovants au travers de quatre études empiriques : la première concerne le processus de conception dans sa globalité, les trois autres études se focalisent sur des points plus spécifiques du processus. Dans la première étude, nous avons cherché à analyser la dynamique globale du processus de co-construction participative et continue des besoins dans le cadre du projet 3DChild. Pour ce, une étude longitudinale a été réalisée et l'observation participante a été nécessaire : l'analyste des données issues du terrain a intégré l'équipe projet comme membre du collectif de conception (chef de projet et ergonome). Dans la seconde étude, nous avons réalisé une expérimentation visant à comprendre comment trois profils de concepteurs identifiaient des besoins et proposaient des spécifications à partir d'une retranscription de description de tâches et d'attentes d'utilisateurs. La troisième étude empirique concerne la priorisation des besoins par différents profils d'utilisateurs du logiciel. Concrètement, les utilisateurs d'Appli-Viz'3D devaient compléter un questionnaire qui contenait une liste de fonctionnalités logicielles anticipées (par les concepteurs) qu'ils devaient prioriser; ils pouvaient également citer des besoins de façon spontanée. La quatrième étude concerne l'élaboration des besoins lors de séances d'utilisation du logiciel ayant lieu à des moments précis et sur des courtes durées. L'analyse de cette activité s'est basée sur l'enregistrement des échanges entre les différents acteurs - concepteurs et utilisateurs - présents lors de ces séances.

Concernant le premier axe organisateur de ce travail, nous démontrons une absence de représentation totalement partagée des notions d'utilité et de besoins par les trois profils de concepteurs : les ingénieurs, les designers et les ergonomes. En effet, nos résultats confirment que les designers imaginent les buts et les fonctionnalités de l'artefact en référence aux contraintes fixées par le commanditaire et par les autres concepteurs, tandis que les ergonomes font essentiellement référence aux besoins, aux manques et aux demandes des utilisateurs finaux, ainsi que par rapport aux bénéfices et aux avantages potentiels que pourrait apporter l'artefact pour l'activité des utilisateurs (c'est-à-dire l'utilité au sens de la valeur). D'autre part, nous mettons en exergue une complémentarité des modèles, des méthodes et des outils, utilisés ou préconisés, associés aux trois phases du processus de conception centrée sur l'utilité ci-après :

- La production d'hypothèses sur les fonctionnalités, les propriétés non-fonctionnelles et les bénéfices attendus;

- La hiérarchisation et la sélection des fonctionnalités, des propriétés non-fonctionnelles et des hypothèses privilégiées en termes de bénéfices et d'avantages;

- La mesure de la pertinence des choix, identification des défaillances, des bénéfices et des avantages.

Concernant le second axe organisateur de cette thèse, nous proposons une caractérisation d'un processus de co-construction participative et continue des besoins et des contributions des concepteurs et des utilisateurs à ce processus. Chaque besoin est traité comme une unité sans prise en compte des fusions et restructuration entre besoins. L'étude d'un tel processus a montré que :

- Une évocation de besoins par des utilisateurs prend essentiellement place en amont et en aval de la réalisation technique;

- Une priorisation de fonctionnalités par les utilisateurs permet de faire émerger de nouveaux besoins;

- Des besoins évoqués par les utilisateurs ne sont pas systématiquement implémentés;

- Des concepteurs produisent des spécifications complémentaires;

- Des réalisations techniques aident les concepteurs à rejeter ou valider les besoins;

- Un apprentissage mutuel est observé entre les concepteurs et les utilisateurs. 
À l'issue de ce travail, nous proposons deux apports méthodologiques : un modèle de conception centrée sur l'utilité et une extension de la méthode II (méthode issue des sciences de l'ingénierie). Le modèle de conception centrée sur l'utilité est original en ce sens qu'il s'agit d'un cadre pour analyser, assister ou guider la prise en compte de l'utilité dans la conception. Il théorise l'existence de deux univers de l'utilité : l'univers prospectif et l'univers rétrospectif. Il formalise l'idée que la conception implique une dialectique continuelle entre les deux univers depuis l'amont de la conception où l'utilité, la forme et le détail du logiciel restent flous et hypothétiques, jusqu'à l'aval où la forme finale est éprouvée et continue à évoluer dans l'usage. D'autre part, nous proposons une extension de la méthode $\mathrm{I}^{2} I$ pour favoriser l'intégration de l'utilisateur dans le processus de conception. En ce sens, elle est un support méthodologique qui vise à guider les ingénieurs en Réalité Virtuelle pour concevoir des produits centrés non seulement sur les caractéristiques, mais aussi sur les besoins et les attentes des utilisateurs. Nos préconisations supposent l'intégration de spécialistes des sciences humaines, ces derniers maîtrisant les méthodes nécessaires à la réalisation de ces étapes.

Ces cadres méthodologiques peuvent outiller les Living Labs du réseau EnoLL (European Network of Living Labs) soutenu par la Commission Européenne. L'objectif des Living Lab est d'engager des communautés d'utilisateurs le plus tôt possible dans le cycle de R \& D afin de co-créer, d'explorer, d'expérimenter et d'évaluer des services, des produits ou des usages nouveaux en amont de la conception. Leur particularité est d'instaurer une dimension participative forte, car l'utilisateur final est intégré dès les premières étapes du processus de conception, et ses besoins sont pris en compte tout au long du projet.

\section{MotS-CLÉS}

Ergonomie, Utilité, Besoins, Réalité Virtuelle, Conception participative.

\section{Abstract}

\section{Towards a usefulness-centered design: an analysis of participative and continuous co-construc- tion of requirements in the context of emerging technologies}

The main objective of this thesis is to support and to improve, with utility in consideration, the design process of artifacts in the context of emerging technologies. It was realized in the context of a Research-Action conducted as part of a real design project called 3DChild, which resulted in a virtual reality based software named "Appli-Viz'3D".

To meet our objective, we have chosen to focus on how utility is effectively dealt today in design community. Two main concerns guided our work. The first one was to analyze how utility and requirements are taken into account in design. From this point of view, we were interested in models, methods and tools used or advocated in marketing, industrial engineering, requirement engineering, software engineering, industrial design and ergonomics of design activities. We also explored representations of different profiles of designers on the utility and key elements in the process of construction of requirements. The second main interest was to study the effective contribution of stakeholders - designers and users - to the design of innovative artifacts through empirical studies. For this second line of research, we first aimed to analyze the global dynamics of the process of participative and continuous co-construction of requirements. We then focused on more specific issues of this process. We were particularly interested in the identification of requirements and in the proposal of specifications by different designers' profiles. We finally studied the prioritization of requirements by different users' profiles and the development of requirements, during the sessions of evaluation of the software Appli-Viz'3D in a participative context.

At the end of this work, we propose two methodological contributions: a model of utility-centered design and an extension of a design method that is the I'I method. The model of utility-centered design is original because it is a framework to analyze, help or guide the inclusion of the utility in the 
design process. It theorizes the existence of two universes of utility: the prospective and retrospective universes. It formalizes the idea that the design involves a continuous dialectic between these two universes from the "analysis" phase where utility, form and detail of the software remain vague and speculative, to the "evaluation and test" phase where the final form is proven and continues to evolve in use. We propose also an extension of the I'I method in order to facilitate the integration of the user in the design process. In this sense, it is a methodological tool which aims to guide VR engineers to design products focused not only on the features, but also on the needs and expectations of end users. Our recommendations involve the integration of human specialists to achieve these steps.

These methodological frameworks may provide tools for the Living Labs belonging to the European Network of Living Labs (EnoLL) supported by the European Commission. The objective of the Living Lab is to engage communities of users as soon as possible in the design process to co-create, explore, experiment and evaluate services, products or new uses before the implementation of an artifact. Their particularity is to establish a strong participatory dimension, because the end users, for whom the new product (or service) is built, is involved in the early stages of the design process, and their needs are taken into account throughout the project.

KEYWORDS

Ergonomics, Utility, Requirements, Virtual Reality, Participative Design. 